\title{
Natriuretic peptides, obesity and cardiovascular diseases
}

\section{Peptídeos natriuréticos, Obesidade e doenças CARDIOVASCULARes}

\author{
Yaniel Castro-Torres $^{1}$, Richard E. Katholi ${ }^{2}$ \\ 'Professor, University Policlinic Santa Clara, Santa Clara, Villa Clara, Cuba \\ ${ }^{2}$ Clinical professor of Medicine and Pharmacology - Southern Illinois University School of Medicine, Springfield, Illinois, USA
}

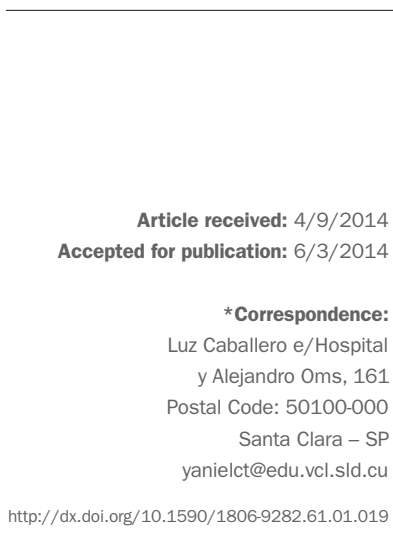

Conflict of interest: none

\section{SUMmaRY}

Obesity, hypertension and heart failure are conditions commonly associated with each other. Recent investigations have demonstrated that low plasmatic levels of natriuretic peptides are linked with obesity. Thus, knowing the actions of these hormones in water and salt homeostasis, it is possible to establish that low levels of natriuretic peptides may be the common denominator among obesity, hypertension and heart failure. Knowledge on this topic is crucial to develop further investigation for definitive conclusions.

Keywords: natriuretic peptides, obesity, hypertension heart failure, cardiovascular diseases, overweight.
Obesity is a significant health concern and represents an important risk factor for the development of cardiovascular diseases. ${ }^{1}$ Despite progress in the management of this condition and the development of new health policies, the incidence of persons who are overweight or obese continues to rise. These people are at an increased risk to suffer from cardiovascular disorders with hypertension (HTN) and heart failure (HF) being the most frequent. ${ }^{2,3}$ The pathogenesis of obesity is multifactorial resulting from interaction of biological, social and environmental factors. ${ }^{4}$ However, current investigations have elucidated some aspects of this pathogenesis which explain an association among a high body mass index, HTN and HF.

Recent research has examined the influence of natriuretic peptides (NPs) on adipose tissue. They have demonstrated that NPs have lipolytic effects and that NP deficiency facilitates an increase in body mass index (obesity). ${ }^{5,6} \mathrm{NPs}$ also influence sodium and water homeostasis and are linked with HTN and HF pathophysiology. NPs facilitate diuresis, natriuresis, vasodilatation, and inhibit sympathetic outflow. These actions decrease blood pressure and reduce cardiac overload volume in patients with $\mathrm{HF}^{7,8}$

From our point of view, these mechanisms suggest a relationship among low plasma levels of NPs, obesity and cardiovascular diseases (HTN and HF).

The metabolic pathway that explains the lipolytic actions of NPs was discovery recently. It begins with the pro- duction of these hormones in cardiac chambers. Then, they act through 4 guanylyl cyclase receptors of NPs located in several tissues, including adipose tissue. After a binding of the receptor they facilitate an increased production of cyclic guanosine monophosphate, which acts as a second messenger. This process is followed by an activation of protein kinase $G$, which induces hormone sensitive lipase phosphorylation, favoring triglycerides degradation. However, this is not the only antilipolytic mechanism of NPs. Protein kinase $\mathrm{G}$ can also activate p38 MAPK (mitogen activated protein kinase) enzyme turning on the brown fat thermogenic program. Brown fat stimulation increases energy expenditure and heat generation. ${ }^{9}$

This knowledge suggests that obesity is related to the development of HTN and HF due to decrease in a common denominator among these conditions, namely NPs.

This hypothesis should be explored in further studies. However, work published by Moro et al. ${ }^{10}$ adds insight to this problem. These researchers found that lipid mobilization in subcutaneous adipose tissue due to physical exercise observed in overweight patients was associated with a rise in plasma levels of atrial NP. This finding supports the association between low NP concentrations and obesity and explains the beneficial effects of physical exercise in body mass reduction and improved blood pressure control.

Recently, another study demonstrated a genetic polymorphism of corin (enzyme that transforms pro-atrial 
NP into atrial NP) with enhanced concentric cardiac hypertrophy in response to high systolic blood pressure in African American patients. ${ }^{11} \mathrm{~A}$ change in corin function promotes reduction or modification in NP concentration and increases the risk of HTN and HF.

Other investigations have also found an inverse relationship between NP plasma levels and the incidence of $\mathrm{HTN}^{12,13}$ and HF, ${ }^{14,15}$ which supports the biological actions of these hormones. The finding of NP deficiency and the development of obesity ${ }^{5,16}$ suggests that a primary decrease in NP concentration results in a reduction in fatty acid degradation which increases the probability of developing obesity. Simultaneously, due to low plasma levels of these hormones, there is a rise in hydrosaline retention, promotion of vasoconstriction and an increase in sympathetic outflow, increasing the probability to develop HTN and/or HF. In this case, both overweight/obesity and the above mentioned diseases appear in the same patient. This theory may be a new explanation for the associations observed among these conditions.

The possibility that low plasma levels of NPs represent the common denominator between obesity and the development of HTN and HF can open new strategies to treat these patients such as modifying NPs levels and/or intervening in their metabolic pathways. There is already a new field of investigation that involves the synthesis of NPs using amino acid insertion, substitution or deletion, which could be very useful in clinical practice. ${ }^{17,18}$

For now, the relationship among obesity, HTN, HF and low levels of NPs as a trigger of this association should be further evaluated. If this hypothesis is confirmed, new strategies to achieve better quality of life for our patients will need to be developed.

\section{References}

1. Go AS, Mozaffarian D, Roger VL, Benjamin EJ, Berry JD, Borden WB, et al. Heart disease and stroke statistics-2013 update: a report from the American Heart Association. Circulation 2013;127:e6-245.

2. Lau DCW, Douketis JD, Morrison KM, Hramiak IM I, Sharma AM, Ur E. 2006 Canadian clinical practice guidelines on the management and prevention of obesity in adults and children [summary]. CMAJ 2007;176:S1-13.

3. Tsigos C, Hainer V, Basdevant A, Finer N, Fried M, Mathus-Vliegen E, et al. Management of obesity in adults: European clinical practice guidelines. Obes Facts 2008;1:106-16.

4. Bray GA. Etiology and pathogenesis of obesity. Clin Cornerstone 1999; 2:1-15.

5. Wang TJ, Larson MG, Levy D, Benjamin EJ, Leip EP, Wilson PW, et al. Impact of obesity on plasma natriuretic peptide levels. Circulation 2004;109: 594-600.

6. Sugisawa T, Kishimoto I, Kokubo Y, Makino H, Miyamoto Y, Yoshimasa Y. Association of plasma B-type natriuretic peptide levels with obesity in a general urban Japanese population: the Suita Study. Endocr J 2010;57: 727-33.

7. Grewal AS, Fitzpatrick M, Stansbury L, Grigore AM. The heart as an endocrine system. Int Anesthesiol Clin 2012;50:111-27.

8. Levin ER, Gardner DG, Samson WK. Natriuretic peptides. N Eng J Med 1998;339:321-8.

9. Castro Torres Y, Fleites Pérez A. Péptidos natriuréticos y obesidad. Un acercamiento a un tópico de interés. Rev Fed Arg Cardiol 2013;42:7-14.

10. Moro C, Pillard F, de Glisezinski I, Klimcakova E, Crampes F, Thalamas C, et al. Exercise-induced lipid mobilization in subcutaneous adipose tissue is mainly related to natriuretic peptides in overweight men. Am J Physiol Endocrinol Metab 2008;295:E505-13.

11. Rame JE, Drazner MH, Post W, Peshock R, Lima J, Cooper RS, et al. Corin I555(P568) allele is associated with enhanced cardiac hypertrophic response to increased systemic afterload. Hypertension 2007;49:857-64.

12. John SW, Krege JH, Oliver PM, Hagaman JR, Hodgin JB, Pang SC, et al. Genetic decreases in atrial natriuretic peptide and salt-sensitive hypertension. Science 1995;267:679-81.

13. Lopez MJ, Wong SK, Kishimoto I, Dubois S, Mach V, Friesen J, et al. Saltresistant hypertension in mice lacking guanylyl cyclase-A receptor for atrial natriuretic peptide. Nature 1995;378:65-8.

14. Maisel AS, Krishnaswamy P, Nowak RM, McCord J, Hollander JE, Duc P, et al. Rapid measurement of B-type natriuretic peptide in the emergency diagnosis of heart failure. N Engl J Med 2002;347:161-7.

15. Doust JA, Glasziou PP, Pietrzak E, Dobson AJ. A systematic review of the diagnostic accuracy of natriuretic peptides for heart failure. Arch Intern Med 2004;164:1978-84.

16. Koizumi M, Watanabe H, Kaneko Y, Ino K, Ishida M, Kosaka T, et al. Impact of obesity on plasma B-type natriuretic peptide levels in Japanese communitybased subjects. Heart Vessels 2012;27:287-94.

17. Lee CYW, Lieu H, Burnett JC. Designer natriuretic peptides. J Investig Med 2009;57:18-21

18. Zakeri R, Burnett JC. Designer natriuretic peptides: a vision for the future of heart failure therapeutics. Can J Physiol Pharmacol 2011;89:593-601.

\section{ERRATUM}

http://dx.doi.org/10.1590/1806-9282.61.03.290

In the article "Natriuretic peptides, obesity and cardiovascular diseases", published in the journal Rev Assoc Med Bras, vol. 61, n. 01: p.19-20, on page 19, where it reads:

“Yaniel Castro Torres ${ }^{1 *}$ ”

“'Professor, Universtity Policlinic José Ramón León Acosta, Santa Clara, Villa Clara, Cuba”

It should read:

“Yaniel Castro-Torres ${ }^{1 *}$ ”

"'Professor, University Policlinic Santa Clara, Santa Clara, Villa Clara, Cuba" 